\title{
Production stages, microbiological risk and benefits on health of herbal teas
}

\author{
GÜL AKDUMAN*®, IREM OMURTAG KORKMAZ®
}

\author{
Department of Nutrition and Dietetics \\ Faculty of Health Sciences \\ Marmara University \\ 34854 Istanbul, Turkey
}

*corresponding author: phone: +90 21633020 70/1323; fax: +90 201639962 42; e-mail: gul.ogren@marmara.edu.tr

\section{Summary}

Plants have been used to prepare herbal infusions for centuries. Production of herbal tea consists of several steps, beginning with harvesting, cleaning form residues, drying, storage of herb in a suitable material, grinding, and blending. Te plants grow in different regions and climatic conditions, varying by their physical properties. They are consumed for different purposes and due to their chemical constituents. Many of them have therapeutic effects. Besides their various benefits and even antimicrobial effects, they also carry some microorganisms. Thus, the botanical characteristics and effects on the health of frequently consumed herbal teas and recommendations on their consumption with considered microbial risks are reviewed in this article.

Key words: herbal tea, health, contamination, antioxidant

Słowa kluczowe: herbata ziołowa, zdrowie, zanieczyszczenie, działanie antyoksydacyjne

\section{INTRODUCTION}

Fresh or dried fruits, leaves, flowers, roots, seeds or stems are collected and then infused or macerated in order to prepare for consumption, usually just before use. Roots, rhizomes, and crustaceans are used for boiling or maceration, while leaves, flowers, and sensitive parts are usually suitable for infusion. Thus, tea might be macerated by soaking the herb material at a room temperature for $\sim 30$ minutes and infusion can be prepared by pouring herbal tea with boiling water and held for $\sim 5-15$ minutes $[1,2]$.

For ages, plant material and herbal teas have been used in the treatment of many diseases. The World Health Organization (WHO) states that about 4 billion people have tried herbal products as first in health problems [3]. As a result of this 
interest in herbs, tea consumption worldwide also increased annually by 4.5 percent to 5.5 million tonnes over the decade to 2016 [4]. According to a study of tea consumption statistics made in 2013, in Turkey lime tea was the most frequently consumed herbal tea $(59.1 \%)$, which was followed by sage tea, rosehip, green tea, mint-lemon tea, chamomile tea, mint tea, blackberry tea, lemon tea, apple tea, cinnamon-cloves tea, and others [5].

The composition of soil, distance to equator, and altitude of the region where the plant grows affects the yield of harvest. The width and size of the tea leaves vary according to the amount of water taken from the soil. This can change the characteristics of herbal teas. Variation in tea products is not only because of different raw material but also because of the difference in the process. Some procedures require only drying (e.g. in white tea production), whereas sometimes additional processes such as steaming, rolling, drying and fermentation [6].

\section{STAGES OF HERBAL TEA PRODUCTION}

The first stage of production of herbal tea is harvesting at the appropriate time depending on the part of herb. Aboveground parts of herbaceous plant should be piled up at the beginning of flowering and at the end of vegetation. The leaves should be collected before flowering, and underground parts and stem collected before drying, whereas fruits should be collected after maturation [7].

The next step is the removal of dirt. This process can be performed manually or mechanically. Thereafter, drying (in $80^{\circ} \mathrm{C}$ ) is carried out either under the sunlight or under the shade or via hot air assisted method. In this phase, the target is to reach the lowest water content $(<0.40)$ fast and without loss of material. This process minimizes mold and causes insect damage on the product, thus herb can be stored for a long time. However, a suitable contact material is important to establish cool, non-humid, and dark environment for safe storage [7].

Then, a grinding stage is applied to obtain smaller particles. At this stage, achieving the appropriate grinding degree is essential to prevent a blurry infusion. On the other hand, the material used for storage also affects grinding degree of herbal tea. As a last stage, blending is performed to obtaind different herbal tea mixture. Supplementation of vitaminmineral or sweetener can be done according to the products' features $[7,8]$.

\section{FREQUENTLY CONSUMED HERBAL TEAS}

\section{Linden tea (Tilia cordata Miller, Tilia platy- phyllos Scop.)}

The linden plant is a tree from the Tiliaceae family. Its species are used for different purposes, such as Tilia cordata and Tilia platyphyllos are preferred due to their therapeutic effects, and Tilia vulgaris is consumed as an herbal tea [9]. It grows in Europe, North America, China, and as well as in Northern Turkey [10].

This plant contains various types of flavonoids (quercetin, isoquercitrin, astragalin, hyperoside, rutin, tyloside, quercetin-3,7-O- $\alpha$-L-diramnoside, camphorol-3,7-O- $\alpha$-L-diramnoside), condensed tannins (procyanidin B2), essential oils (linalool, geraniol, geranyl acetate, farnesol, farnesilacetate, 1,8-cineol, 2-phenyl alcohol, phenyl-ethyl benzoate, alkanes), mucilages (uronic acids), phenolic acids (caffeic acid, $p$-coumaric acid, chlorogenic acid) and amino acids in its chemical structure [11].

Its flowers' benefits for health such as antispasmodic, diaphoretic, hypotensive, diuretic, tranquilizing, anticonvulsant, analgesic, and chest softening are well-known. Linden tea is used especially against cold and cough, as a sedative and diuretic $[12,13]$. These effects of linden tea originate from flavonoids, mucilages, and oils [9, 14]. Although there is no available report on its side effect, its usage for longer time than 2 months is not recommended [10].

\section{Sage tea (Salvia officinalis L.)}

Sage (Salvia officinalis L., Salvia triloba L.) belongs to the Lamiaceae family. It is a perennial plant with $50-100 \mathrm{~cm}$ height, purplish-blue flowers, simple leaf. The wild type of this plant is found in Central Europe and Western Balkans. It is also cultured in Turkey. Its leaves, flowers, and essential oils are used for various purposes $[15,16]$. The genus Salvia (Lamiaceae) spread throughout the world (nearly 900 species worldwide). Only in Turkey this genus has 89 species with a total of 94 taxa, of which 45 are endemic in Turkey [15]. Additionally, Salvia tomentose, a large flowering sage species that grows especially in high regions of coastal areas, is grown in Turkey and its leaves are consumed as a tea. Sage has fringe roots with a length ranging from $60 \mathrm{~cm}$ to $100 \mathrm{~cm}$ [17]. Dried leaves of Salvia 
fruticosa (Salvia triloba) is a commonly consumed tea in Turkey $[16,17]$.

The chemical structure of this plant contains several essential oils ( $\alpha$ - and $\beta$-thuyene, camphor, cineol, borneol), tannins, and bitter substances. It contains various flavonoids and phenolic compounds (5-methoxysalvigenin, apigenin, hispidulin, cirimaritin). Carnosol, carnosic acid, rosmadial, rosmanol, epirosmanol, and methyl carnosate are the most important phenolic components. Caffeic acid (sagecoumarin), polysaccharides, and some estrogenic substances are also included $[15,16]$.

Sage is an aromatic herb with antioxidant activity, which reduces lipid oxidation. The total antioxidant activity of sage is higher than $\alpha$-tocopherol [18]. This herb has also antidiabetic properties. Sage may inhibit gluconeogenesis or glycogenolysis in the liver, by its fasting glucose-reducing effect [19]. Sage also has various pharmacological effects such as the increase of pain tolerance, analgesic, and antiinflammatory activity [20].

\section{White, green, oolong, and black tea (Camellia sinensis)}

Camellia sinensis belongs to the Theaceae family, which is an evergreen tea. Plant leaves of Camellia sinensis are used for tea production through different methods. Differences between the processes lead to the formation of different tea species; i.e. black tea, green tea, and oolong tea. White tea is produced by drying process. Japanese style green tea is produced by steaming, rolling, and drying, whereas Chinese style green tea is produced by withering, pan firing, rolling/shaping, and drying. Oolong tea is produced by solar withering rolling, semi fermentation, and tray drying. Black tea is produced by withering, rolling, fermentation, and tray drying of Camellia sinensis [6]. In a study, tea was found as a most frequently consumed beverage after water and $20-28.8 \%$ of total tea consumption was green tea in Turkey $[5,21]$.

Tea production started in China and reached Europe through the Arabian tribes. In nature, it grows up to $10-15 \mathrm{~m}$ in height, but cultivates of this tree are shorter. Its leaves are short, light green, crustacean, and about $4 \mathrm{~cm}$ wide. Young leaves are pubescent, mature leaves are bright green coloured, skinny and smooth. The flowers are white, fragrant, $2.5-4 \mathrm{~cm}$ in diameter. Today tea is produced mostly in India, South Russia, East Africa, Java, Sri Lanka, Sumatra, Argentina, and Turkey [22].
At the beginning of $8^{\text {th }}$ century, green tea was transported from China to Japan. Thereafter, green tea consumption began to spread throughout the world. Its unique flavour and smell put it among the most commonly consumed beverages. Some proteins and carbohydrates contain sources of fiber in the water-insoluble form of the leaves of green tea leaves. If the tea leaves contact with hot water, only the components with small molecular weight can pass into the water [23]. Polyphenols (flavonols, hydroxyl-4-flavanols, anthocyanins, flavones, flavonols and phenolic acids (gallic, caffeic, and chlorogenic acids) constitute its $25-35 \%$ of the dry weight [23]. Especially, kaempferol, myricetin and quercetin from flavonols; catechins $(( \pm)$-epicatechin (EC), (-)-epicatechin gallate (ECG), ( \pm )-epigallocatechin (EGC) and (-)-epigallocatechin gallate (EGCG)) from flavans are found abundantly in the structure of green tea [24]. Caffein is also mentioned as a green tea component. After a 5-minute infusion process, the amount of caffeine in the green tea leaves was determined as $0.086-2.23 \mathrm{mg} / \mathrm{g}$ [25].

Camellia sinensis has a high antioxidant properties regarding its phenolic components and some vitamins in its structure. The fermentation process affects its components as well. Therefore, the unfermented sort of tea, i.e. green tea, has more antioxidant properties than black tea and oolong tea [26]. Free radical scavengers green tea help protect cardiovascular system health, has anti-aging activity, and prevent cancer cells' formation [27, 28]. It is known that polysaccharides, polyphenols, and caffeine found in green tea are effective for increasing the metabolic rate and prevention from obesity and adipose tissue formation [29].

\section{Chamomile tea (Matricaria chamomilla)}

The chamomile (Matricaria chamomilla L.) in Asteraceae family is one of the most important medicinal plants of Southern and Eastern Europe. It is endemic in Europe, e.g. Germany, Hungary, France, Russia, former Yugoslavia areas, NorthWest Asia, North America, and in Brazil. It also grows near to roads in Turkey. Hungary is the primary producer of chamomile and this plant is a good income source for people of the region [30, 31]. Chamomile is a seasonal plant, with fine spindle-shaped roots. It grows up to $10-80 \mathrm{~cm}$ and has long and narrow leaves. Its threaded yellow tubular flowers are $1.5-2.5 \mathrm{~mm}$ long, white plant flowers are 6-11 $\mathrm{mm}$ long [31]. 
M. chamomilla belongs to a large group of medicinal plants. Its active compounds have promoted its therapeutic use. The most important bioactive components it contains are sesquiterpenes, flavonoids, coumarins, and polyacetylenes. (Z)- and (E)-2 $\beta$-d-glucopyranosyloxy-4-methoxycinnamic acid (GMCA), the precursor of glucoside herniarin, glucagon, luteolin, and luteolin-7-0-glucoside (flavons), quercetin and rutin (flavonols) and naringenin (flavanone), herniarin and umbelliferone (coumarin), chlorogenic acid and caffeic acid (phenylpropanoids), apigenin [31]. It also contains essential oils such as bisabolol oxide A, $\alpha$-bisabolol, bisabolol oxide $\mathrm{B}$, cis-enyne-bicycloether, bisabolol oxide, chamazulene, spathulenol, and (E)- $\beta$ farnesene [32].

Antimicrobial, antifungal, anticancer, antimutagenic, antidiabetic, antiviral, antiinflammatory, and antiprotozoal activities are determined in the essential oils of chamomile. Its phenolic compounds have antioxidant properties, which provide a cellular damage-inhibiting effect caused by free radicals $[33,34]$. The apigenin found in the structure of chamomile has a pronounced affinity at the benzodiazepine receptors. This explains the mechanism of a sedative effect. It also significantly reduces the severity of hot flashes in postmenopausal women, alleviating sleep disturbances, and fatigue $[35,36]$. By-products may be generated related to the high consumption of the leaves of $M$. chamomille, which may cause allergic reactions due to the photoactivation of the coumarins [37].

\section{Fennel tea (Foeniculum vulgare)}

Foeniculum vulgare, a family of Umbelliferae (Apiaceae), is a delicious medicinal plant used by humans since antiquity. It grows naturally in the Mediterranean region and Europe, Asia, North Africa, South America. F. vulgare is a vertical, perennial plant that grows up to 2 meters and has soft, hairy leaves. It has a large number of branched with smooth, polished, and bright green leaves. Its leaves grow up to $40 \mathrm{~cm}$ long and have a final section like a filiform about $0.5 \mathrm{~mm}$ wide. Its flowers bloom in July and August $[38,39]$.

F. vulgare is a plant that is widely grown and rich in minerals such as potassium, sodium, phosphorus, and calcium. Leaves and stems have the highest moisture content ( 76.36 and $77.46 \mathrm{~g} / 100 \mathrm{~g}$ ) and flowers have the lowest moisture content $(71.31 \mathrm{~g} / 100 \mathrm{~g})$. Carbohydrates are the main macronutrient in all parts of the plant, ranging from 18.44 to $22.82 \mathrm{~g} / 100 \mathrm{~g}$. Proteins are $1.08 \mathrm{~g} / 100 \mathrm{~g}$ in the stalk and $1.37 \mathrm{~g} / 100 \mathrm{~g}$ in the flower buds. 100 grams of the plant contains $0.63 \mathrm{~g}$ of leucine, $0.73 \mathrm{~g}$ of isoleucine, $0.45 \mathrm{~g}$ of phenylalanine, $0.53 \mathrm{~g}$ of tryptophan. It includes approximately $0.55 \mathrm{~g}$ glycine and $0.53 \mathrm{~g}$ proline. Phenolic compounds are important for fruit quality because they affect the taste, color, and nutritional properties of the fruit. Fennel's phenolic compounds contain neochlorogenic acid, chlorogenic acid, gallic acid, caffeic acid, $p$-coumaric acid, ferulic acid7-0-glucoside, quercetin-7-0-glucoside, ferulic acid, 1,5-cinnamic acid, rosmarinic acid, quercetin, and apigenin $[40,41]$.

Fennel is an important substance for polyherbal formulations in the treatment of different diseases and disorders. Several essential oils and phenolic compounds of $F$. vulgare has health-promoting effects such as antiaging, antiallergic, anticholitic, antihirsutism, anti-inflammatory, antimicrobial, antiviral, antimutagenic, antinociceptive, antipyretic, antispasmodic, anxiolytic, apoptotic, antitumor, diuretic, galactogenic, preservative, cytochrome P450 3A4 enzyme system inhibitor, hypoglycemic, hypolipidemic activities, estrogenic, and expectorant [42-44].

\section{Senna tea (Cassia acutifolia, Cassia angustifolia)}

Cassia sp. belongs to the Fabaceae (Leguminosae) family and grows in India and other tropical regions. The plant needs a temperature higher than $10^{\circ} \mathrm{C}$ to grow and humidity similar to coastal areas, riverbanks, waste areas, and a 1000-1400 m height of altitude. Cassia species are wild plants, with a $30-90 \mathrm{~cm}$ high, and have $6-8 \mathrm{~cm}$ long, green, needle year-round leaves. Its flowers usually have five pale yellow leaves [31].

O- $\beta$-D-glucopyranoside, an amorphous light yellow substance, kaempferol-3-O-gentiobioside in a yellow crystal form, and 1,7-dihydroxy-3-carboxyanthraquinone sinamycin in an orange crystal form are three main compounds of senna tea. 3-Ogentiobiose kaempferol is a flavonoid that occurs in this plant [45]. The senna leaves carry anthracene derivatives at rates of $2.5-3.5 \%$. It contains chrysophanol, aloe-emodin, and mucilage [46].

Cassia species has various benefits for health such as antitumor, anthelmintic, antibacterial, antioxidant, anti-inflammatory, and antidiabetic effects. However, it has healing effects on obesity and hepatic lipogenesis [47-51]. Cinnamon leaf has also 
a laxative effect, however, its long-term use results in severe electrolyte losses [52].

\section{Ginger (Zingiber officinale)}

Ginger belongs to the family Zingiberaceae and one of the most important and common spices in the world. It has spread to many tropical and subtropical countries from the Sino-Indian region. In ancient times, ginger played an important role in primary health care in India and China. Ginger is used as a pharmaceutical in European medicine. It has thin, short (rarely $50 \mathrm{~cm}$ in length), sticky, or fairly short leaves. It can reach up to $150 \mathrm{~cm}$ in height [53].

Oleoresin and total essence of ginger are responsible for ginger flavour. Gingerol and shogaol are two important compounds in the structure of oleoresin, which contribute to the ginger flavor. In long-term storage, ginger converts to shogaol. The quality of ginger depends on the relative content of gingerol and shogaol. Its essential oils are composed of $20-25 \%$ of oleoresins (camphor, $\beta$-phelandrene, 1,8-cineole, geranial, and neral) and additionally, it contains also sesquiterpenes. Gingerols, shogaols, and their phenol ketone derivatives are bitter compounds for the building of these essential oils $[53,54]$.

Ginger is an effective plant in prevention of vomiting and bulimia. It also has a lowering effect on insulin resistance in individuals with type 2 diabetes. Antioxidative and anti-inflammatory effects protect cells against the damage of free radicals and have positive effects on cardiovascular health [55-58].

\section{Mate tea (Ilex paraguariensis)}

The tea was obtained by drying the leaves of the Ilex paraguariensis plant from the Aquifoliaceae family is frequently consumed in the south Latin American countries. Mate grows endemically in southern regions of South America (Brazil, Argentina, Paraguay, Uruguay). In recent years, it has spread rapidly into the world market. It can reach to $18 \mathrm{~m}$ height, is a leafless, long-lasting plant. It grows in regions with high precipitation and at an average annual temperature of $21-22^{\circ} \mathrm{C}$, which can withstand up to $-6^{\circ} \mathrm{C}[59]$.

The chemical structure of mate is rich in polyphenols, which mainly consist of chlorogenic acid $(92 \mathrm{mg}$ equivalents per gram in its dry leaf). In blended teas, the amount of this component is considerably reduced [60]. Mate is a source of methylxanthines and also consists of theophylline (1,3-dimethylxanthine), theobromine (3,7-dimethylxanthine) and caffeine (1,3,7-trimethylxanthine). Among these components, caffeine has the highest concentrations (1-2\% of dry weight). This is followed by theobromine, which is present as $0.3-0.9 \%$ in its dry weight. In a cup of mate tea $(\sim 150 \mathrm{ml}) 78 \mathrm{mg}$ caffeine content is estimated [61, 62]. Caffeoyl derivatives of mate include caffeic acid, chlorogenic acid, 3,4-dicaffeoylquinic acid, 3,5-dicapoylquinic acid, and 4,5-dicapoylicinic acid [63]. Saponins are also present in flavor compounds in mate tea [59].

The caffeoyl derivatives of mate tea contain routine, tannin, and ursolic acid as the main constituents of its antioxidant capacity. Caffeine has anticancerogenic, antiobesity, antioxidant, antitumoral, diuretic, energizing, stimulant, topoisomerase-1 inhibitor effects $[64,65]$. It is proven that mate tea gives positive results on obesity and weight management [65]. Cytotoxicity studies showed an anti-cancer activity by providing TPA-stimulated ornithine decarboxylase, quinone reductase activities through HepG2 cells, and topoisomerase inhibition by using Saccharomyces cerevisiae [67]. Several frequently consumed herbal teas regarding their chemical composition and purpose of usage are presented in table 1.

\section{MICROBIAL RISKS}

Dried herbs can be contaminated with pathogens at any point in the production chains (cultivation, harvesting, processing, packaging, storage, and marketing). Contamination of soil and irrigation water, animal-borne contaminants, and contaminations from field workers may cause the growth of fungi or bacteria. Microorganisms can be transferred to the leaves from the hands or harvesting equipment during the production (cultivation) or harvesting. Omagbai et al. [68] found several fungi (Aspergillus niger, Aspergillus flavus, Penicillum expansum, Rhizopus stolonifer, Fusarium solanii) and bacteria (Staphylococcus aureus, Staphylococcus epidermidis, Bacillus subtilis, Pseudomonas aeruginosa, Escherichia coli, Klebsiella pneumonia, Serratia marcencens, Salmonella typhimurium, Pseudomonas fluorescens) on the herbal teas in their microbiologically study. The bacterial content of herbal teas varied between $1.1 \mathrm{x}$ $10^{1}$ and $3.6 \times 10^{2}$ colony forming unit $(\mathrm{cfu}) / \mathrm{g}$, whereas the fungal content varied between $1.3 \times 10^{2}$ and $4.5 \times 10^{5} \mathrm{cfu} / \mathrm{g}$ in their study [68]. In another study by Tournas and Katsoudas [69], the mold-yeast content of different tea types was studied and the moldyeast contamination rate was up to $1.4 \times 10^{5} \mathrm{cfu} / \mathrm{g}$. All 
Table 1.

Bioactive compounds and the effects of herbal teas

\begin{tabular}{|c|c|c|c|c|c|}
\hline Herbal tea & Family & \multicolumn{2}{|c|}{ Compounds } & Purpose of usage & References \\
\hline $\begin{array}{l}\text { Linden tea } \\
\text { (Tilia sp.) }\end{array}$ & Tiliaceae & $\begin{array}{l}\text { quercetin } \\
\text { isoquercitrin } \\
\text { astragalin } \\
\text { hyperoside } \\
\text { rutin } \\
\text { tyloside } \\
\text { camphorol } \\
\text { procyanidin } \\
\text { linalool }\end{array}$ & $\begin{array}{l}\text { geraniol } \\
\text { geranyl acetate } \\
\text { farnesol } \\
\text { farnesilacetate } \\
\text { 1,8-cineol } \\
\text { 2-phenyl alcohol } \\
\text { phenyl-ethyl benzoate } \\
\text { alkanes }\end{array}$ & $\begin{array}{l}\text { antispasmodic } \\
\text { diaphoretic } \\
\text { hypotensive } \\
\text { diuretic } \\
\text { tranquilizing } \\
\text { anticonvulsant } \\
\text { analgesic } \\
\text { chest softening }\end{array}$ & {$[9,11-13]$} \\
\hline $\begin{array}{l}\text { Sage tea } \\
\text { (Salvia sp.) }\end{array}$ & Lamiaceae & $\begin{array}{l}\text { 5-methoxysalvigenin } \\
\text { apigenin } \\
\text { hispidulin } \\
\text { sirimaritin }\end{array}$ & $\begin{array}{l}\text { camphor } \\
\text { cineol } \\
\text { borneol }\end{array}$ & $\begin{array}{l}\text { antioxidant } \\
\text { antidiabetic } \\
\text { pain tolerance } \\
\text { analgesic } \\
\text { anti-inflammatory }\end{array}$ & {$[15,16,18,20]$} \\
\hline $\begin{array}{l}\text { White, Green, } \\
\text { Oolong, Black } \\
\text { Tea } \\
\text { (Camellia } \\
\text { sinensis) }\end{array}$ & Theaceae & $\begin{array}{l}\text { kaempferol } \\
\text { mycerin } \\
\text { quercetin } \\
\text { catechins } \\
\text { epicatechin }\end{array}$ & $\begin{array}{l}\text { epicatechin gallate } \\
\text { epigallocatechin } \\
\text { epigallocatechin gallate } \\
\text { caffeine } \\
\text { theophylline } \\
\text { theobromine }\end{array}$ & $\begin{array}{l}\text { stimulates the central nervous } \\
\text { system } \\
\text { antioxidant } \\
\text { diuretic } \\
\text { antibacterial }\end{array}$ & {$[6,23,29,61]$} \\
\hline $\begin{array}{l}\text { Chamomile tea } \\
\text { (Matricaria } \\
\text { chamomilla) }\end{array}$ & Asteraceae & $\begin{array}{l}\text { luteolin } \\
\text { quercetin } \\
\text { rutin } \\
\text { naringenin } \\
\text { herniarin } \\
\text { umbelliferone }\end{array}$ & $\begin{array}{l}\text { chlorogenic acid } \\
\text { caffeic acid } \\
\text { apigenin } \\
\text { bisabolol oxides } \\
\text { bicycloether, spathulenol } \\
\text { (e)- } \beta \text {-farnesene }\end{array}$ & $\begin{array}{l}\text { antimicrobial } \\
\text { antifungal } \\
\text { anticancer } \\
\text { antimutagenic } \\
\text { antidiabetic } \\
\text { antiviral } \\
\text { antiinflamatuar }\end{array}$ & {$[30-34]$} \\
\hline Fennel tea & Umbelliferae & $\begin{array}{l}\text { neochlorogenic acid } \\
\text { chlorogenic acid } \\
\text { allic acid } \\
\text { caffeic acid } \\
\text { coumaric acid }\end{array}$ & $\begin{array}{l}\text { ferulic acid } \\
\text { quercetin } \\
\text { cinnamic acid } \\
\text { rosmarinic acid } \\
\text { apigenin }\end{array}$ & $\begin{array}{l}\text { antiaging } \\
\text { antiallergic } \\
\text { anticholitic } \\
\text { anti-inflammatory } \\
\text { antimicrobial } \\
\text { antimutagenic } \\
\text { antispasmodic } \\
\text { hypolipidemic }\end{array}$ & $\begin{array}{l}{[38-41,43,44,} \\
68]\end{array}$ \\
\hline $\begin{array}{l}\text { Senna tea } \\
\text { (Cassia sp.) }\end{array}$ & Fabaceae & $\begin{array}{l}\text { anthraquinone } \\
\text { aloe-emadins } \\
\text { chrysophanol }\end{array}$ & & $\begin{array}{l}\text { antitumor } \\
\text { anthelmintic } \\
\text { antibacterial } \\
\text { antioxidant } \\
\text { anti-inflammatory } \\
\text { antidiabetic }\end{array}$ & {$[31,47-51]$} \\
\hline $\begin{array}{l}\text { Ginger tea } \\
\text { (Zingiber } \\
\text { officinale) }\end{array}$ & Zingiberaceae & $\begin{array}{l}\text { Ooleoresin } \\
\text { sesquiterpenes } \\
\text { gingerols } \\
\text { shogaols }\end{array}$ & & $\begin{array}{l}\text { antiemetic } \\
\text { antioxidative } \\
\text { anti-inflammatory }\end{array}$ & {$[53-58]$} \\
\hline $\begin{array}{l}\text { Mate tea } \\
\text { (Ilex } \\
\text { paraguariensis) }\end{array}$ & Aquifoliaceae & $\begin{array}{l}\text { chlorogenic acid } \\
\text { theophylline } \\
\text { theobromine } \\
\text { caffeine } \\
\text { tannin } \\
\text { ursolic acid }\end{array}$ & $\begin{array}{l}\text { caffeic acid } \\
\text { chlorogenic acid } \\
\text { 3,4-dicaffeoylquinic acid } \\
\text { 3,5-dicapoylquinic acid } \\
\text { 4,5-dicapoylicinic acid }\end{array}$ & $\begin{array}{l}\text { anticancerogenic } \\
\text { antiobesity } \\
\text { antioxidant } \\
\text { antitumoral } \\
\text { diuretic } \\
\text { energizing } \\
\text { stimulant }\end{array}$ & {$[59,60,63,64]$} \\
\hline
\end{tabular}


of the herbal teas analyzed in the same study were found to be contaminated with mesophilic aerobic bacteria (MAB, minimum $1.6 \times 10^{3}$, maximum $1.2 \mathrm{x}$ $10^{7} \mathrm{cfu} / \mathrm{g}$ [68]. In the study of Vidović et al. [70], 67\% of the herb samples had a MAB content higher than $10^{6} \mathrm{cfu} / \mathrm{g}$ and a significant increase in MAB content was detected during the processing of raw materials. In the same study, mold and yeast content were noted between 3.13 and $4.41 \log _{10} \mathrm{cfu} / \mathrm{g}$ [70].

It is important to minimize the microbial content with the correct heat treatments without loss of healthy effects of the tea. Temperatures above $80^{\circ} \mathrm{C}$ significantly reduce microbial loads on tea leaves. However, fungi such as Aspergillus can grow in low water activities, care must be taken to dry the product quickly to prevent such growth and possible production of toxic metabolites [71, 72]. Particularly mycotoxins the secondary metabolites of fungi and several heat resistant bacterial pathogens, such as Cronobacter sakazakii, can cause a decrease in the beneficial effect of herbal tea on health.

\section{CONCLUSIONS}

Herbal teas are commonly consumed in most countries. Many studies proved their health benefits. However, there is still lack of knowledge on their safe consumption levels. In addition, due to their allergic potential and other unexpected results, pregnant and lactating women and people with specific illnesses should consult a doctor before consuming herbal teas. Therefore, it seems that predictive studies are needed to investigate its usage, particularly in susceptible populations and assessment of the potential risks and benefits. Especially risk assessment approaches can be combined with consumption habits in order to estimate the exposure to toxicological and/or microbial hazards of herbs.

Ethical approval: The conducted research is not related to either human or animal use.

Conflict of interest: Authors declare no conflict of interest.

\section{REFERENCES}

1. European Medicines Agency. Glossary on herbal teas. https://www.ema.europa.eu/en/documents/ regulatory-procedural-guideline/glossary-herbal-teas_en.pdf. Accessed 08 July 2020.
2. Wachira FN, Kamunya S, Karorl S, Chalo R, Maritim T. The tea plants: botanical aspects. In: Preedy VR (ed.). Tea in health and disease prevention. $1^{\text {st }}$ ed. Academic Press 2012:3-18.

3. Faydaoğlu E, Sürücüoğlu MS. History of the use of medical and aromatic plants and their economic importance. Kastamonu Univ Orman Fak Derg 2011; 11(1):52-67.

4. FAO 2018. Current market situation and medium term outlook. Intergovernmental group on tea. http://www.fao.org/3/BU642en/bu642en.pdf. Accessed 08 July 2020.

5. Ulusoy A, Şeker M. Türkiyede değişen çay tüketim alışkanlıkları projesi (the project of changing consumption habits tea in Turkey). https://issuu. com/8698858/docs/t_rkiye_de__de_i_en_ cay_t_keti. Accessed 08 July 2020 [in Turkish].

6. Hilal Y, Engelhardt U. Characterisation of white tea. Comparison to green and black tea. J Verbrauch Lebensm 2007; 2(4):414-421. doi: https:// dx.doi.org/10.1007/s00003-007-0250-3

7. Akgül A, Ünver A. Bitkisel Çaylar. Gıda Mühendisliği Dergisi TMMOB Gıda Mühendisleri Odası 2001; 11:21-24 [in Turkish].

8. Mishra BB, Gautam S, Sharma A. Microbial decontamination of tea (Camellia sinensis) by gamma radiation. J Food Sci 2006; 71(6):151156. doi: https://dx.doi.org/10.1111/j.17503841.2006.00057.x

9. İncedayı B. A research on some properties of carbonated linden herbal tea beverage. Gida 2007; 42(4):355-363. doi: https://dx.doi.org/10.15237/ gida.GD17025

10. Söhretoğlu D. Tilia Cordota, Tilia platyphyllos, Ihlamur. In: Demirezer LÖ eds. Tedavide Kullanılan Bitkiler. $1^{\text {st }}$ ed. Ankara 2011: 679-682.

11. Prchalová J, Kovařík F, Rajchl A. Evaluation of the quality of herbal teas by DART/TOF-MS. J Mass Spectrom 2017; 52(2):116-126. doi: https:// dx.doi.org/10.1002/jms.3905

12. Cárdenas-Rodríguez N, González-Trujano ME, Aguirre-Hernández E, Ruíz-García M, Sampieri A, Coballase-Urrutia E, Carmona-Aparicio L. 
Anticonvulsant and antioxidant effects of Tilia americana var. mexicana and flavonoids constituents in the pentylenetetrazole-induced seizures. Oxid Med Cell Longev 2014. doi: https://dx.doi. org/10.1155/2014/329172

13. Federici E, Multari G, Gallo FR, Palazzino G. Herbal drugs: from traditional use to regulation. Ann Ist Super Sanita 2005; 41:49-54. https:// dx.doi.org/0.1016/j.taap.2007.10.005

14. Aguirre-Hernandez E, Gonzalez-Trujano ME, Martinez AL, Moreno J, Kite G, Terrazas T, SotoHernandez M. HPLC/MS analysis and anxiolytic-like effect of quercetin and kaempferol flavonoids from Tilia americana. J Ethnopharm 2010; 127:91-97. doi: https://dx.doi.org/10.1016/j. jep.2009.09.044

15. Akin M, Demirci B, Bagci Y, Baser KHC. Antibacterial activity and composition of the essential oils of two endemic Salvia sp. from Turkey. Afr J Biotechnol 2010; 9(15):2322-2327. doi: https:// dx.doi.org/10.5897/AJB2010.000-3037

16. Tosun A, Tatlı İI. Salvia officinalis, Tibbi Adaçayı. In: Demirezer LÖ (ed.). Tedavide Kullanılan Bitkiler. $1^{\text {st }}$ ed. Ankara. 2011:615-618 [in Turkish].

17. Ekren S, Sönmez Ç, Sancaktaroğlu S, Bayram E. The effect of different harvesting heights on the agronomical and technological properties of sage (Salvia officinalis L.) genotypes. Ege Üniv Ziraat Fak Derg 2007; 44(1):55-70.

18. Önenç SS, Açıkgöz Z. Antioxidant effects of aromatic plants on animal products. Hayvansal Üretim 2005; 46(1):50-55.

19. Lima CF, Azevedo MF, Araujo R, FernandesFerreira M, Pereira-Wilson C. Metformin-like effect of Salvia officinalis (common sage): is it useful in diabetes prevention? Br J Nutr 2006; 96(2):326-333. doi: https://dx.doi.org/10.1079/ bjn20061832

20. Karami M, Shamerani MM, Hossini E, Gohari AR, Ebrahimzadeh MA, Nosrati A. Antinociceptive activity and effect of methanol extracts of three Salvia spp. on withdrawal syndrome in mice. Adv Pharm Bull 2013; 3(2):457-459. doi: https://dx.doi.org/ 10.5681/apb.2013.075

21. Çelik F. Çay (Camellia sinensis); içeriği, sağlık üzerindeki koruyucu etkisi ve önerilen tüketimi.
Turkiye Klinikleri J Med Sci 2006; 26(6):642-648 [in Turkish].

22. Ross IA. Medicinal plants of the world. Vol 3. $1^{\text {st }}$ ed. New Jersey 2010:1-28.

23. Chaturvedula VSP, Prakash I. The aroma, taste, color and bioactive constituents of tea. J Med Plants Res 2011; 5(11):2110-2124.

24. Kim HS, Quon MJ, Kim JA. New insights into the mechanisms of polyphenols beyond antioxidant properties; lessons from the green tea polyphenol, epigallocatechin 3-gallate. Redox Biol 2014; 2:187-195. doi: https://dx.doi.org/10.1016/j.redox.2013.12.022

25. El-Shahawi MS, Hamza A, Bahaffi SO, Al-Sibaai AA, Abduljabbar TN. Analysis of some selected catechins and caffeine in green tea by high performance liquid chromatography. Food Chem 2012; 134(4):2268-2275. doi: https://dx.doi. org/10.1016/j.foodchem.2012.03.039

26. Shahidi F, Ambigaipalan P. Phenolics and polyphenolics in foods, beverages and spices: Antioxidant activity and health effects - a review. J Funct Foods 2015; 18:820-897. doi: https://dx.doi. org/10.1016/j.jff.2015.06.018

27. Fujiki H, Sueoka E, Watanabe T, Suganuma M. Primary cancer prevention by green tea, and tertiary cancer prevention by the combination of green tea catechins and anticancer compounds. J Cancer Prev 2015; 20(1):1-4. doi: https://dx.doi. org/ 10.15430/JCP.2015.20.1.1

28. Onakpoya I, Spencer E, Heneghan C, Thompson $\mathrm{M}$. The effect of green tea on blood pressure and lipid profile: a systematic review and metaanalysis of randomized clinical trials. Nutr Metab Cardiovasc Dis 2014; 24(8):823-836. doi: https:// dx.doi.org/10.1016/j.numecd.2014.01.016

29. Xu Y, Zhang M, Wu T, Dai S, Xu J, Zhou Z. The anti-obesity effect of green tea polysaccharides, polyphenols and caffeine in rats fed with a highfat diet. Food Funct 2015; 6(1):297-304. doi: https://dx.doi.org/10.1039/c4fo00970c

30. Barnes J, Anderson LA, Phillipson JD, Newall CA. Herbal medicines. $3^{\text {rd }}$ ed. London 2007:459.

31. Singh O, Khanam Z, Misra N, Srivastava MK. Chamomile (Matricaria chamomilla L.): An 
overview. Pharmacogn Rev 2011; 5(9):82-95. doi: https://dx.doi.org/10.4103/0973-7847.79103

32. Orav A, Raal A, Arak E. Content and composition of the essential oil of Chamomilla recutita (L.) Rauschert from some European countries. Natur Pro Res 2010; 24(1):48-55. doi: https:// dx.doi.org/10.1080/14786410802560690

33. Ögüt, S. Importance of natural antioxidants. J Adnan Menderes Univ Agric Fac 2014; 11(1):25-30.

34. Raut JS, Karuppayil SM. A status review on the medicinal properties of essential oils. Ind Crops Prod 2014; 62:250-264. doi: https://dx.doi. org/10.1016/j.indcrop.2014.05.055

35. Gün Ç, Demirci N. Herbal treatment in menopause. Archiv Med Rev J 2015; 24(4):520-530. doi: https://dx.doi.org/10.17827/aktd.52798

36. Haghi G, Hatami A, Safaei A, Mehran M. Analysis of phenolic compounds in Matricaria chamomilla and its extracts by UPLC-UV. Res Pharm Sci 2014; 9(1):31-37.

37. Petrulová-Poracká V, Repcák M, Vilková $M$, Imrich J. Coumarins of Matricaria chamomilla L.: aglycones and glycosides. Food Chem 2013; 141(1):54-59. doi: https://dx.doi.org/10.1016/j. foodchem.2013.03.004

38. Badgujar SB, Patel VV, Bandivdekar AH. Foeniculum vulgare Mill: a review of its botany, phytochemistry, pharmacology, contemporary application, and toxicology. Biomed Res Int 2014. doi: https://dx.doi.org/10.1155/2014/842674

39. Krishnamurthy KH. Medicinal plants: Madhuri$\mathrm{ka}$, saunf or fennel (Foeniculum vulgare Gaertn.). J New Appl Med Health 2011; 19(1):1-4.

40. Barros L, Carvalho AM, Ferreira ICFR. The nutritional composition of fennel (Foeniculum vulgare): shoots, leaves, stems and inflorescences. LWT Food Sci Technol 2010; 43(5):814-818. doi: https://dx.doi.org/10.1016/j.lwt.2010.01.010

41. Roby MHH, Sarhan MA, Selim KA, Khalel KI. Antioxidant and antimicrobial activities of essential oil and extracts of fennel (Foeniculum vulgare L.) and chamomile (Matricaria chamomilla L.). Ind Crops Prod 2013; 44:437-445. doi: https:// dx.doi.org/10.1016/j.indcrop.2012.10.012
42. Koppula S, Kumar H. Foeniculum vulgare Mill. (Umbelliferae) attenuates stress and improves memory in Wistar rats. Trop J Pharm Res 2013. doi: https://dx.doi.org/10.4314/tjpr.v12i4.17

43. Rahimi R, Ardekani MR. Medicinal properties of Foeniculum vulgare Mill. in traditional Iranian medicine and modern phytotherapy. Chin J Integr Med 2013; 19(1):73-79. doi: https://dx.doi. org/10.1007/s11655-013-1327-0

44. Rasul A, Akhtar N, Khan BA, Mahmood T, Uz Zaman S, Khan HM. Formulation development of a cream containing fennel extract: in vivo evaluation for anti-aging effects. Pharmazie 2012; 67(1):54-58.

45. Kurkin VA, Anna AS. The development of new approaches to standardization of Cassia acutifolia leaves. J Pharmacogn Phytochem 2014; 3(3):163167.

46. Yilmaz G. Cassia acutifolia, Cassia angustifolia, Sinameki. In: Demirezer LÖ (ed.). Tedavide Kullanılan Bitkiler. $1^{\text {st }}$ ed. Ankara 2011:109-113 [in Turkish].

47. Demirkol G, Ertürk Ö. Antibacterial and antifungal effects of acetone extracts from fifty spice and herb plants. Herba Pol 2019; 65(3): 32-38. doi: http://dx.doi.org/10.2478/hepo-2019-0016

48. Kundu S, Roy S, Lyndem LM. Cassia alata L: potential role as anthelmintic agent against Hymenolepis diminuta. Parasitol Res 2012; 111(3):11871192. doi: https://dx.doi.org/10.1007/s00436-0122950-6

49. Naowaboot J, Wannasiri S. Anti-lipogenic effect of Senna alata leaf extract in high-fat diet-induced obese mice. Asian Pac J Trop Biomed 2016; 6(3):232-238. doi: https://dx.doi.org/10.1016/j. apjtb.2015.12.006

50. Olarte EI, Herrera AA, Villaseñor IM, Jacinto SD. In vitro antitumor properties of an isolate from leaves of Cassia alata L. Asian Pac J Cancer Prev 2013; 14(5):3191-3196.

51. Weidner C, Wowro SJ, Rousseau M, et al. Antidiabetic effects of chamomile flowers extract in obese mice through transcriptional stimulation of nutrient sensors of the peroxisome proliferator-activated receptor (PPAR) family. PLoS 
One 2013; 8(11):e80335. doi: https://dx.doi. org/10.1371/journal.pone.0080335

52. Uzun, MB, Aykaç G, Özçelikay G. Improper use and harms of herbal products. Lokman Hekim J 2014; 4(3):1-5.

53. Ravindran PN, Nirmal Babu KN, Shiva KN. Botany and crop improvement of ginger. In: Ravindran PN, Nirmal Babu KM (eds.). Ginger the Genus Zingiber. $1^{\text {st }}$ ed. New York 2016:15-86.

54. Sener N, Ozkinali S, Gur M, Guney K, Ozkan OE, Khalifa MM. Determination of antimicrobial activity and chemical composition of pimento and ginger essential oil. Indian J Pharm Edu Res 2017; 51(3):230-233. doi: https://dx.doi.org/10.5530/ ijper.51.3s.19

55. Khaki A, Khaki AA, Hajhosseini L, Golzar FS, Ainehchi $\mathrm{N}$. The anti-oxidant effects of ginger and cinnamon on spermatogenesis dys-function of diabetes rats. Afr J Tradit Complement Altern Med 2014; 11(4):1-8. doi: https://dx.doi. org/10.4314/ajtcam.v11i4.1

56. Mashhadi NS, Ghiasvand R, Askari G, Hariri M, Darvishi L, Mofid MR. Anti-oxidative and anti-inflammatory effects of ginger in health and physical activity: review of current evidence. Int J Prev Med 2013; 4(Suppl. 1):36-42.

57. Thomson M, Corbin R, Leung L. Effects of ginger for nausea and vomiting in early pregnancy: a meta-analysis. J Am Board Fam Med 2014; 27(1):115-122. doi: https://dx.doi.org/10.3122/ jabfm.2014.01.130167

58. Yeh HY, Chuang CH, Chen HC, Wan CJ, Chen TL, Lin LY. Bioactive components analysis of two various gingers (Zingiber officinale Roscoe) and antioxidant effect of ginger extracts. LWT-Food Sci Technol 2014; 55(1):329-334. doi: https:// dx.doi.org/10.1016/j.lwt.2013.08.003

59. Heck CI, De Mejia EG. Yerba Mate Tea (Ilex paraguariensis): a comprehensive review on chemistry, health implications, and technological considerations. J Food Sci 2007; 72(9):138151. doi: https://dx.doi.org/10.1111/j.17503841.2007.00535.x

60. Atoui AK, Mansouri A, Boskou G, Kefalas P. Tea and herbal infusions: their antioxidant ac- tivity and phenolic profile. Food Chem 2005; 89:27-36. doi: https://dx.doi.org/10.1016/j.foodchem.2004.01.075

61. Junior ELC, Morand C. Interest of mate (Ilex paraguariensis A. St.-Hil.) as a new natural functional food to preserve human cardiovascular health - a review. J Funct Foods 2016; 21:440-454. doi: https://dx.doi.org/10.1016/j.jff.2015.12.010

62. Blum-Silva CH, Chaves VC, Schenkel EP, Coelho GC, Reginatto FH. The influence of leaf age on methylxanthines, total phenolic content, and free radical scavenging capacity of Ilex paraguariensis aqueous extracts. Rev Bras Farmacogn 2015; 25:1-6. doi: https://dx.doi.org/ 10.1016/j. bjp.2015.01.002

63. Peşin İIlex Paraguariensis, Mate. In: Demirezer LÖ (ed.). Tedavide Kullanılan Bitkiler Ankara 2011:321-327 [in Turkish].

64. Mateos R, Baeza G, Sarriá B, Bravo L. Improved LC-MSn characterization of hydroxycinnamic acid derivatives and flavonols in different commercial mate (Ilex paraguariensis) brands. Quantification of polyphenols, methylxanthines, and antioxidant activity. Food Chem 2018; 241:232241. doi: https://dx.doi.org/10.1016/j.foodchem.2017.08.085

65. Wu TW, Lee CC, Hsu WH, Hengel M, Shibamoto T. Antioxidant activity of natural plant extracts from mate (Ilex paraguariensis), Lotus Plumule (Nelumbo nucifera Gaertn.) and Rhubarb (Rheum rhabarbarum L.). J Food Nutr Disord 2017; 6(3). doi: https://dx.doi.org/10.4172/23249323.1000225

66. Gambero A, Ribeiro ML. The positive effects of yerba maté (Ilex paraguariensis) in obesity. Nutrients 2015; 7(2):730-750.

67. Pérez JM, Maldonado ME, Rojano BA, Alzate F, Sáez J, Cardona W. Comparative antioxidant, antiproliferative and apoptotic effects of Ilex laurina and Ilex paraguariensis on colon cancer cells. Trop J Pharm Res 2014; 13(8):1279-1286. doi: https://dx.doi.org/10.4314/tjpr.v13i8.12

68. Omogbai, BA., Ikenebomeh, M. Microbiological characteristics and phytochemical screening of some herbal teas in Nigeria. Eur Sci J 2013; 9(18). 
69. Tournas VH, Katsoudas EJ. Microbiological quality of various medicinal herbal teas and coffee substitutes. Microbiology Insights 2008; 1:47-55.

70. Vidović S, Cvetkovic D, Ramić M, Dunjić M, Malbaša $R$, Tepić A et al. Screening of changes in content of health benefit compounds, antioxidant activity and microbiological status of medicinal plants during the production of herbal filter tea. Ind Crops Prod 2013; 50:338-345. doi: https://dx.doi.org/10.1016/j.indcrop.2013. 08.005
71. Hsu WY, Simonne A, Jitareerat P, Marshall MR Jr. Low-dose irradiation improves microbial quality and shelf life of fresh mint (Mentha piperita L.) without compromising visual quality. J Food Sci 2010; 75(4):222-230. doi: https://dx.doi. org/10.1111/j.1750-3841.2010.01568.x

72. Wilson C, Dettenkofer M, Jonas D, Daschner FD. Pathogen growth in herbal teas used in clinical settings: a possible source of nosocomial infection? Am J Infect Control 2004; 32(2):117-119. doi: https://dx.doi.org/10.1016/j.ajic.2003.09.004 